\title{
Delineation of Sedimentary Thickness of Lafia and Environs Using Aeromagnetic Data
}

\author{
Oguadinma T. C., Aku M. O.
}

\begin{abstract}
Aeromagnetic data over Lafia and environs have been analyzed to delineate the sedimentary thickness (Depth to Basement) and describe lineament features. Aeromagnetic data of the area comprising sheets 210 (Wamba), 211 (Kwolla), 231 (Lafia) and 232 (Akiri) covering an area of about 12,100 $\mathrm{km}^{2}$ located between latitudes $8^{\circ} 00^{\prime} \mathrm{N}$ and $9^{\circ} 00^{\prime} \mathrm{N}$ and longitudes $8^{\circ} 30^{\prime} \mathrm{E}$ and $9^{\circ} 30^{\prime} \mathrm{E}$ were obtained from the Nigerian Geological Survey. Visual study of the Total magnetic intensity map, residual anomaly map and lineament maps show the presence of major lineament features trending NE-SW and NNE-SSW while the minor features trending E-W and NW-SE. Six profiles taken across the generated residual map were subjected to spectral depth analysis revealed two depth sources; the deeper magnetic sources range from 2.13 to $4.89 \mathrm{~km}$, while the shallower magnetic sources range from 0.86 to $2.06 \mathrm{~km}$. These shallower sources are probably due to the presence of igneous intrusives and/or magnetized bodies within the sedimentary cover. The temperature at depth ranges from $54.52^{\circ} \mathrm{C}$ to $183.48^{\circ} \mathrm{C}$ with an average of $100.15^{\circ} \mathrm{C}$. The South western and central parts of the study area were delineated as potential hydrocarbon target area due to the right temperature and sedimentary thickness.These areas correspond to Ajo, Obi, Keana, Abudem, Awena and areas between Ungwan Mai Samari and Kolen towns.
\end{abstract}

Index Terms - Aeromagnetic, Lafia and Environs, Sedimentary thickness, Spectral Analysis, Temperature estimate.

\section{INTRODUCTION}

The earth and its contents have long been of an interest to humans, in a bid to unravel its complexity and understand its origin and the resources therein; various geophysical methods are used to study it. The analysis of these measurements can reveal how the earth interior varies both vertically and laterally, and the interpretation of which can reveal meaningful information on the geological structures beneath (Dobrin \& Savit 1988). A wide range of geophysical methods exist with a distinct operative physical property which determines its applicability. Magnetic method is very suitable for locating buried magnetic ore bodies because of their magnetic susceptibility. Geophysical methods for detecting discontinuities, faults, joints and other basement structures include the following: magnetics, seismic, electrical, potential field, well logging, gravity, radiometric, thermal etc (Correl \& Grauch 1985).The gravity and

Oguadinma Timothy Chidindu, Department of Physics, College of Natural and Pharmaceutical Sciences,Bayero University,Kano, Nigeria

Aku Musa Ogah, Department of Physics, College of Natural and Pharmaceutical Sciences, Bayero University,Kano, Nigeria magnetic methods can provide information on Earth properties at greater depths and inaccessible areas especially if the survey is airborne (Hinze,1990). The aim of a magnetic survey is to investigate subsurface geology on the basis of magnetic anomalies in the Earth's magnetic field resulting from the magnetic properties of the underlying rocks (Ikumbur et al, 2013) and in determining depth to magnetic source bodies (sedimentary thickness). According to Paterson and Reeves (1985) and Anudu et al (2012), the applications of aeromagnetic surveys are useful in delineating faults, shear zones and fractures.

Sedimentary thickness required for hydrocarbons to form or be generated varies from place to place. The minimum sediment thickness required for producing oil usually varies from $2 \mathrm{~km}$ to $4 \mathrm{~km}$, compared to $3 \mathrm{~km}$ to $7 \mathrm{~km}$ for gas production/formation (Dow1978, Gluyas \& Swarbrick 2005) .The temperature range in which oil forms (i.e. source rock maturation) known as oil window is often found in the $60-120^{\circ} \mathrm{C}$ intervals. Several works have been carried out on the Benue Trough's tectonic framework such as Ajakaiye et al., (1986) and Olasehinde et al., (1990) delineating NE-SW and ENE-WSW directions as being the dominant magnetic lineament trends. According to Nur et al. (1994), Onyedim et al. (2006) and Onwuemesi (1997), using various methods obtained sedimentary thickness range of $0.066 \mathrm{~km}$ to $4.94 \mathrm{~km}$, $0.11 \mathrm{~km}$ to $5.5 \mathrm{~km}$ and 0.9 and $5.6 \mathrm{~km}$ respectively in the Benue trough. Anudu et al., (2012) analysed an aeromagnetic data over Wamba and its adjoining areas employing Peter's (half-slope) estimated sedimentary thickness delineating deeper sources ranging from $0.88 \mathrm{~km}$ to $3.15 \mathrm{~km}$ and shallower sources ranging from $0.23 \mathrm{~km}$ to $0.76 \mathrm{~km}$. Igwesi \&Umego, (2013) Obtained the average depth to basement of Lower Benue trough to be $3.03 \mathrm{~km}$ suggesting enough sedimentary thickness for hydrocarbon accumulation. Likkason et al., (2013) conducted a study onthe Middle Benue Trough based on geological application and analyses of Spectra of aeromagnetic data. Results from the plot of log radial spectrum against the frequency numbers indicate magnetic layers ranging from $20.62 \mathrm{~km}$ (highest) to $0.26 \mathrm{~km}$ (lowest). This work focused on the analysis of a total field aeromagnetic data covering parts of Middle Benue Trough using spectral analysis to determine the depth to magnetic sources. Nwazeapu, (1992) asserted that one major challenge in the discovery of hydrocarbon in the Nigerian sector of the Chad Basin has been the presence of intrusive igneous bodies in most of the wells drilled and the study area is no exception. There is therefore great need to re-evaluate the geology of the basin since two basins (Niger-Delta and Anambra Basins) in Nigeria that are beneath the study area are productive. 
Aeromagnetic survey is rapid and cost effective technique to access a wide area

\section{LOCATION AND GEOLOGY OF THE STUDY AREA}

The study area is located mostly in Nasarawa state, and partly in Plateau State in north-central Nigeria. It is located between latitudes $8^{\circ} 00^{\prime} \mathrm{N}$ and $9^{\circ} 00^{\prime} \mathrm{N}$, and longitudes $8^{\circ} 30^{\prime} \mathrm{E}$ and $9^{\circ} 30^{\prime} \mathrm{E}$ (Fig. 1). The study area is underlain by the basement complex rocks, younger granites and Cretaceous Middle Benue Trough's sedimentary rocks (Macleod et al 1971). The basement complex rocks in the area are grouped into two, namely migmatite-gneiss complex and the older granites (Anudu et al, 2012). The predominant and most extensive rock in the northern part of the study area is the migmatite-gneiss complex which is Neo- Proterozoic to Meso-Archean (542Ma-3200Ma) in age and composed of migmatites and gneisses. The older granites component of the basement complex are Pan-African $(600 \pm 200 \mathrm{Ma})$ in age and consist mainly of granites, diorites and dolerites. It can be observed that both the migmatites and gneisses were deformed and intruded by the older granites (or Pan-African granitoids) during the $600 \pm 200 \mathrm{Ma}$ Pan-African episodes (Ajibade, 1982). The younger granites in the study area are Jurassic (145-210Ma) in age mainly consisting of microgranites and biotite granites (Anudu et al.2012). The southern part of the area forms part of the Middle Benue Trough and is underlain by Cretaceous sedimentary rocks, namely the Asu River group, Keana and Awe formation, Eze-aku Formation, Awgu shale and Lafia formation in successive order (Obaje, 2009). Asu River group comprises limestones, shales, micacous siltstones, mudstones and clay. Keana and Awe formation consists of cross-bedded, coarse grained feldsparthic sandstones, occasional conglomerates, and bands of shales and limestones towards the top. Eze-aku Formation is made up mainly of calcareous shales, micaceous fine to medium friable sandstones and beds of limestones which are in places shelly. The Awgu shale is composed mainly of bluish-gray to black shales, whereas the Lafia formation consists mainly of sandstones and claystones.

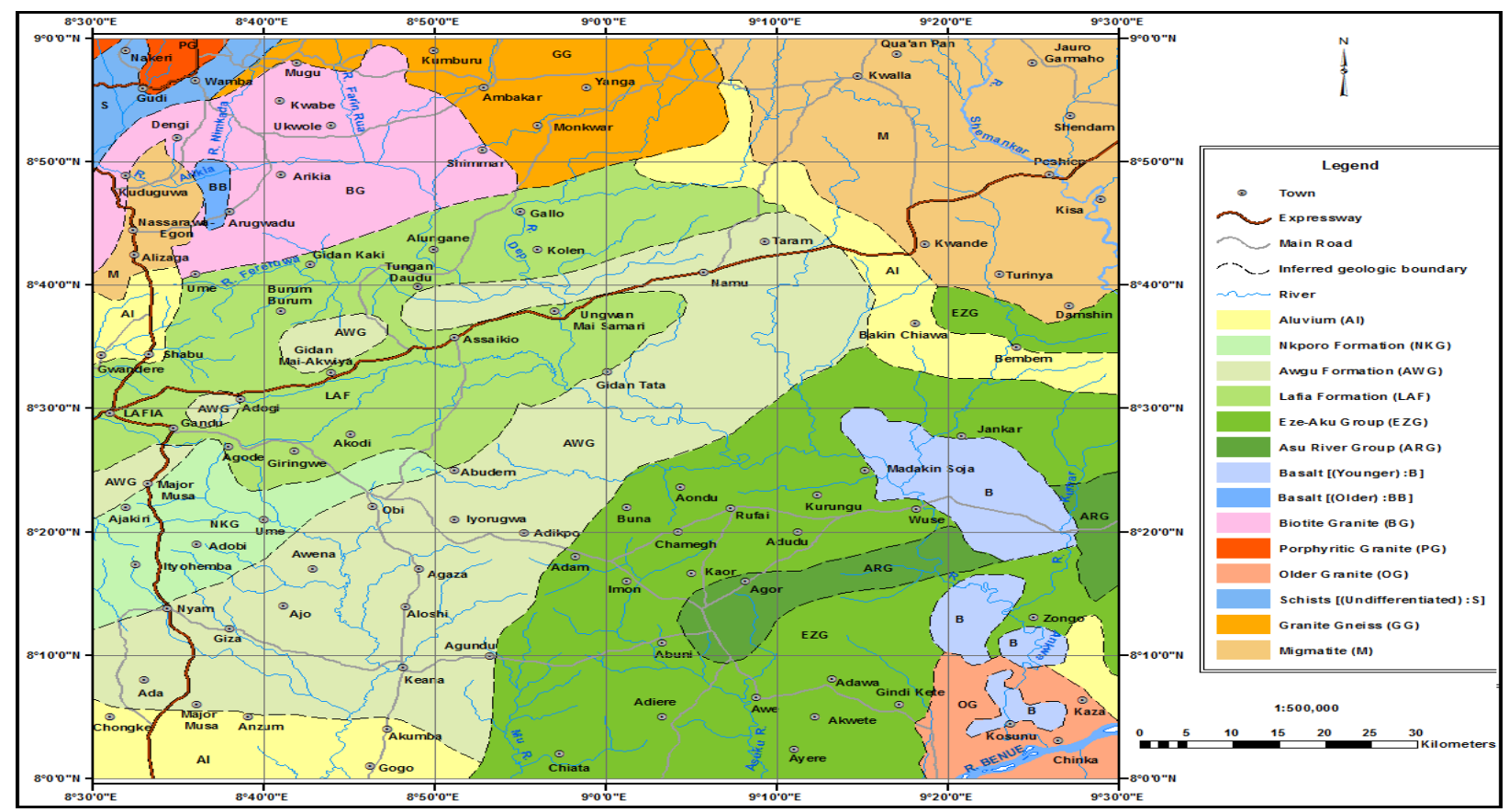

Fig 1: Geology Map of the Study area showing different Formations and Towns

\section{MATERIALS AND METHODS}

The aeromagnetic data were obtained as part of the nationwide aeromagnetic survey sponsored by Geological Survey Agency of Nigeria and Sheet 210 (Wamba), Sheet 211 (Kwolla), Sheet 231 (Lafia) and Sheet 232 (Akiri) covering an area of about $12,100 \mathrm{~km}^{2}$ were used for this study. The data was acquired along a series of Northwest-Southeast flight lines with a spacing of $2 \mathrm{~km}$ and an average flight elevation of about $150 \mathrm{~m}$ while tie lines occur at about $20 \mathrm{~km}$ interval. The geomagnetic gradient was removed from the data using the International Geomagnetic Reference Field (IGRF).These sheets were studied with respect to Longitude, Latitude and total magnetic intensity (TMI) values and integrated in ascending order like Sheet 210-Sheet 211-Sheet
231-Sheet 232 and subsequently contoured using Surfer 12. Separation of Integrated Aeromagnetic Data

To interpret the local field, the regional field was removed from the TMI by fitting a linear trend surface on to the digitized aeromagnetic data by a multiple regression technique. The surface linear equation given according to Davis, (1973) is: $P(x, y)=a x+b y+c$

The trend surface equation (regional gradient) obtained from the data is:

$$
P_{(x y)}=0.003026651 x+0.00660568 y+521.6943356
$$

Moreover, the trend surface equation was then subtracted from the aeromagnetic (observed) data and the resultant residual anomaly was contoured using Surfer 12 software.

Spectral Analysis 
Magnetic anomalies caused by shallow structures are more dominated by high wave number components than those resulting from deeper source. This effect may be quantified by computing the power spectrum of the anomaly since the long power spectrum has a linear gradient whose magnitude is dependent upon the depth of the source (Spector and Grant, 1970). The major advantage of Spectral analysis method is its ability to filter almost all the noise from the data whilst still making sure no information is lost in the process of interpretation by overlapping data operations and are easier in the transform domain (Telford et al. 1990). This is applied to regularly spaced data such as the aeromagnetic data. The Fourier Transform is the basis for spectral analysis and is summarized by Onwuemesi (1997) as shown below:

$Y_{i(x)}=\sum_{n=1}^{N}\left[a_{n} \cos \left(\frac{2 \pi n x_{i}}{L}\right)+b_{n} \sin \left(\frac{2 \pi n x_{i}}{L}\right)\right]$

$\mathrm{n}=$ harmonic number of the partial wave, $\mathrm{N}=$ number of data points

$a_{n}=$ real part of the amplitude spectrum

$b_{n}=$ imaginary part of the amplitude spectrum $\mathrm{i}=0,1,2,3$, ----------------------, $\mathrm{n}$

But,

$$
a_{n}-2 \int^{N} Y_{i} \cos \frac{2 \pi n x_{i}}{*}
$$

Hence, th $\quad b_{n}=\frac{2}{N} \sum_{i=1}^{N} Y_{i} \sin \frac{2 \pi n x_{i}}{L}$
973) as:
Frequency and subsequently obtaining the linear gradient (M) of the linear segment from the low frequency spectrum, hence according to Negi et.al (1983) the depth to basement (Sedimentary thickness) can be obtained thus;

$Z=-\frac{M L}{2 \pi}$

where, ${ }^{z}=$ depth to the basement $\quad ; M=$ gradient of the linear segment $L=$ width of the anomaly

The most important parameter in quantitative interpretation is the depth of the anomalous body. Spectral Analysis was employed and sixprofiles from $\mathrm{EE}^{1}-\mathrm{JJ}^{1}$ was drawn across the residual anomaly map.

Thus, the graphs of the profiles were plotted and the depths to basement were estimated using Fourier Transform method using equation (6). The spreadsheet application Microsoft Excel includes a veritable tool that calculate the discrete Fourier transform (DFT) or its inverse for a set of data.

\section{RESULT AND DISCUSSION}

The qualitative interpretation of the aeromagnetic maps entails critical examination of total magnetic intensity (TMI) and residual anomaly maps in conjunction with the surface relief map and rose diagram in order to reveal the various magnetic signatures, intensities, closures and structural lineaments of the study area. The key essence of the rose diagram was to date the events that produced the rocks from which they were obtained Anudu et al (2012).

$A_{n}=$,

A plot of Natural Logarithm of Amplitude against $8^{\circ 30} \mathbf{E}$

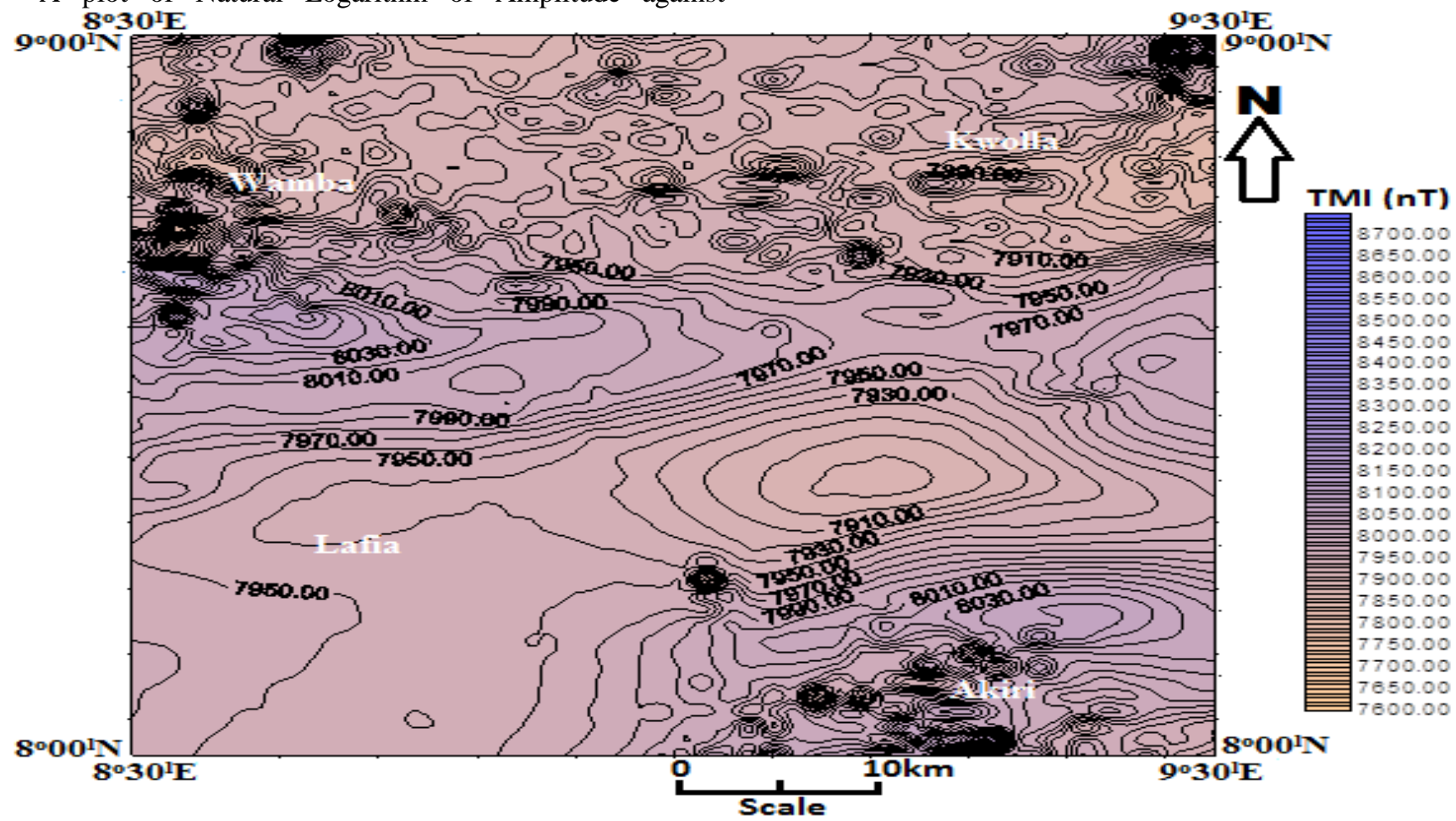

Fig. 2: Total Magnetic Intensity Map of Lafia and Enivrons (Contour Interval 10nT) 


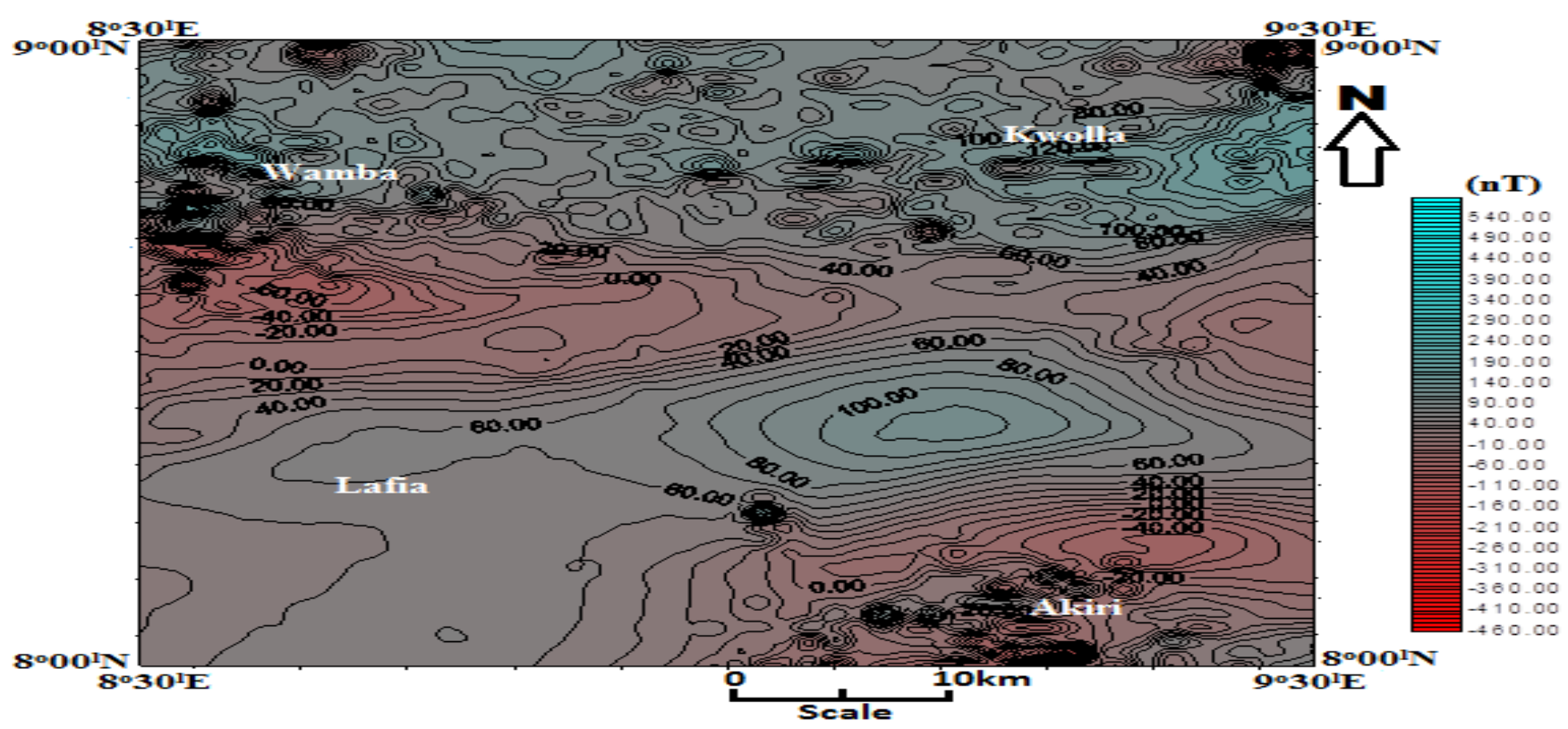

Fig. 3: Residual Anomaly Map of Lafia and Enivrons (Contour Interval 10nT)

The total magnetic intensity (TMI) and residual anomaly maps depict the underlying basement as having magnetic intensities which ranges from 7600 to $8700 \mathrm{nT}$ and -460 to 540 nT respectively (Figs 2 and 3). The Northern part and the South Eastern Part shows closely spaced and clustered contour pattern, which could be indicative of igneous intrusions, magnetic bodies or structural lineaments, this when compared to the South-western and central areas with widely spaced contours and low magnetic values are indicative of thick sedimentary cover and corresponding to the cretaceous sedimentary rock as seen in the geology map. The Rose Diagram clearly shows major lineament trends as NE-SW and NNE-SSW, while the E-W and NNW-SSE are the minor trends. According to previous works such as Obiora (2009), Obaje et al. (2011) they proposed that the NE-SW, NNE-SSW and NW-SE within the study area are regarded as Pan-African Orogeny while the E-W may probably have been Pre-Pan-African Orogeny.

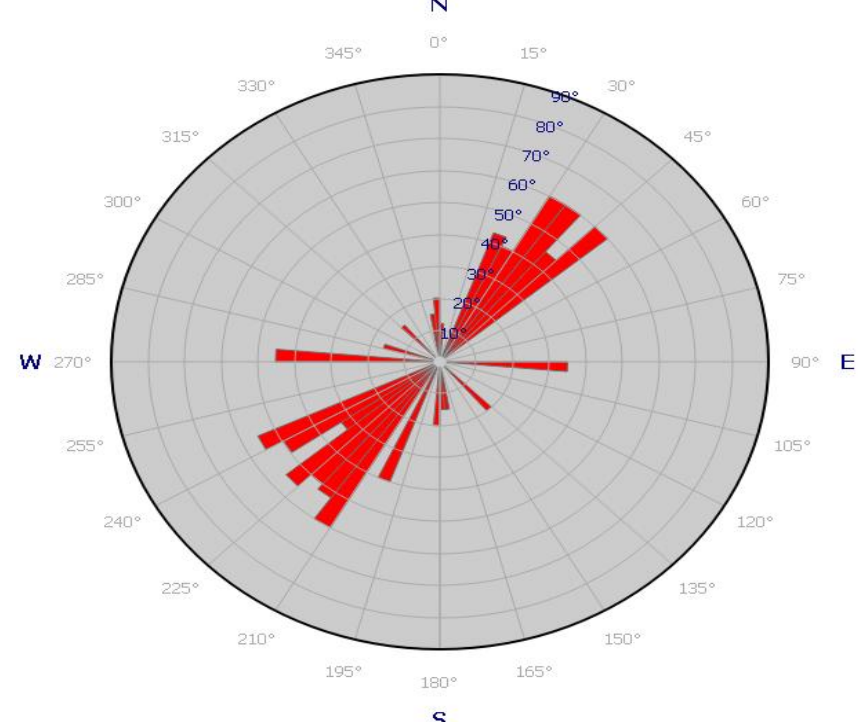

Fig 4: Rose Diagram of structural Lineament trend in the

\section{i. Estimating Depth to Magnetic Bodies}

The six selected magnetic profiles; $\mathrm{E}_{-} \mathrm{E}^{1}, \mathrm{~F}_{-} \mathrm{F}^{1}, \mathrm{G}-\mathrm{G}^{1}, \mathrm{H}-\mathrm{H}^{1}$, $\mathrm{I}^{1} \mathrm{I}^{1}$, and $\mathrm{J}-\mathrm{J}^{1}$ revealed twenty three (23) magnetic anomalous bodies across the profile lines.

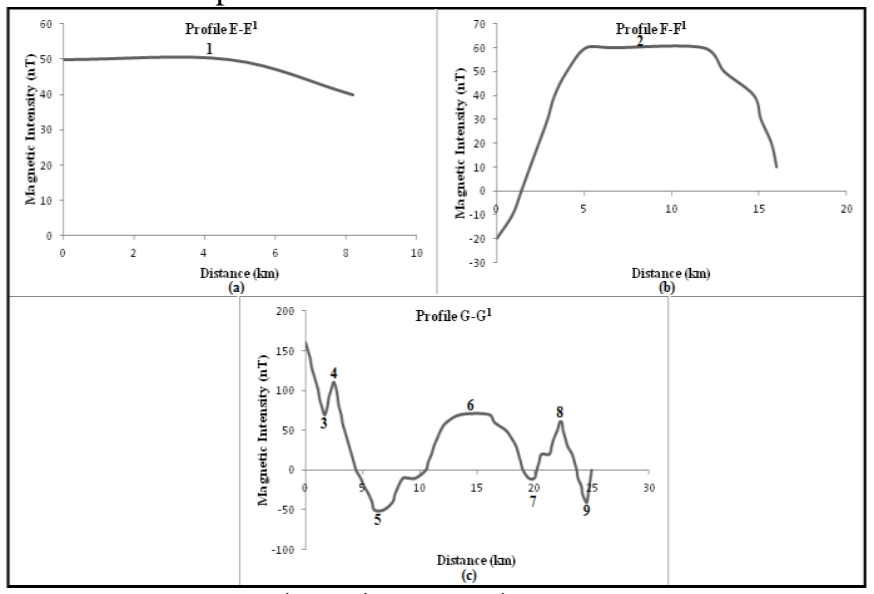

Fig 5a: Profiles E-E ${ }^{1}, F_{-} F^{1}$ and $G-G^{1}$ area. 


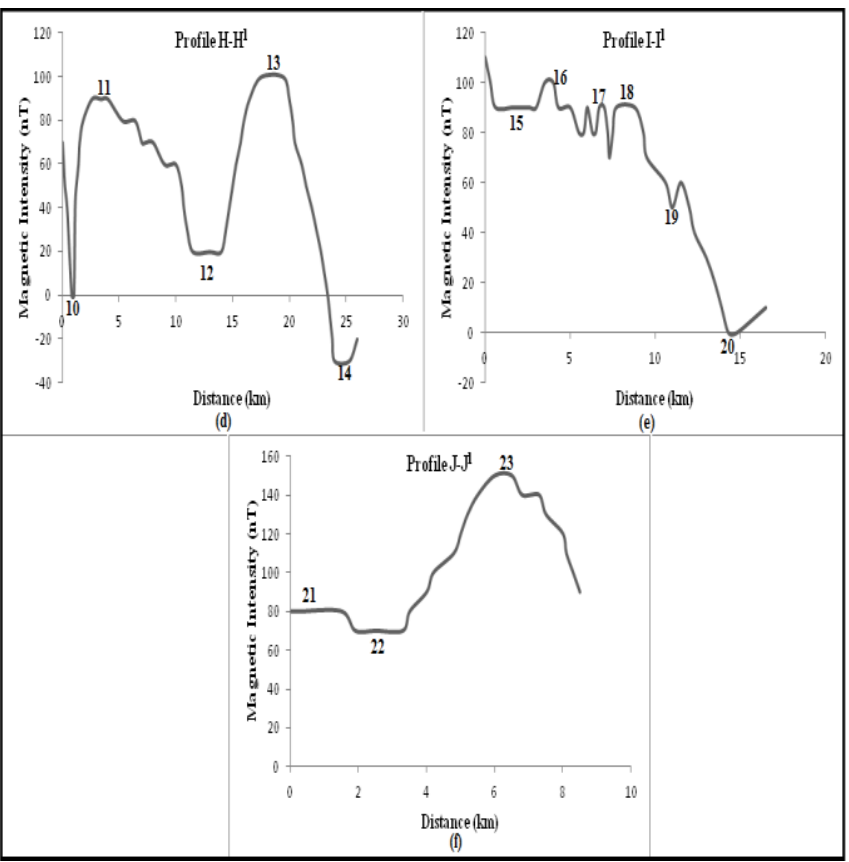

Fig 5b: Profiles $\mathrm{H}-\mathrm{H}^{1}, \mathrm{I}^{-1}$, and J-J ${ }^{1}$

The twenty three (23) magnetic anomalies were subjected to spectral analysis for estimation of depth to the magnetic sources (sedimentary thicknesses). The sample Spectral graph is shown in figure 6 below

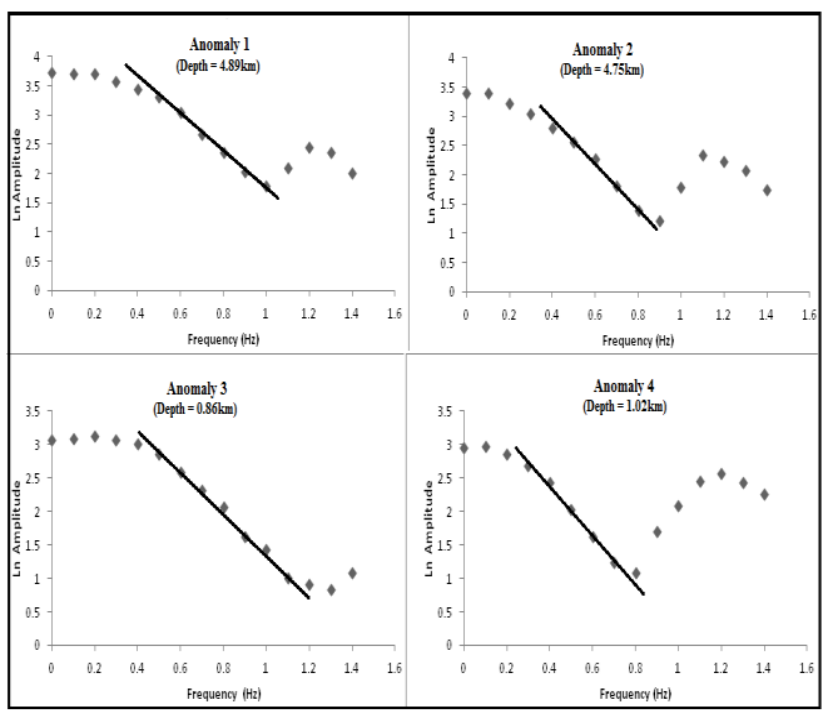

Fig 6: Spectral graph for Anomaly 1-4 in the study area

Two depth models were established. The deeper magnetic sources vary from 2.13 to $4.89 \mathrm{~km}$; whereas the shallow magnetic sources vary from 0.86 to $2.06 \mathrm{~km}$ as shown in Table 1. Deeper magnetic sources may probably represent depths to crystalline basement rocks, while the shallower magnetic sources may represent depths to basic intrusive and/or magnetized bodies within the sedimentary cover. The sedimentary cover is thicker in the south-western, central and eastern parts of the study area and trending Southwest-North east direction.

Table 1: Estimation of Depth to the top of magnetic sources and Temperature at Depth

\begin{tabular}{|c|c|c|c|}
\hline Profile Name & Anomaly No. & Depth $(\mathrm{km})$ & Temperature at Depth $\left({ }^{\circ} \mathrm{C}\right)$ \\
\hline E-E & 1 & 4.89 & 183.48 \\
\hline F-F ${ }^{1}$ & 2 & 4.75 & 179.00 \\
\hline \multirow{7}{*}{ G- $\mathrm{G}^{1}$} & 3 & 0.86 & 54.52 \\
\hline & 4 & 1.02 & 59.64 \\
\hline & 5 & 2.31 & 100.92 \\
\hline & 6 & 4.63 & 175.16 \\
\hline & 7 & 2.70 & 113.40 \\
\hline & 8 & 1.55 & 76.60 \\
\hline & 9 & 0.92 & 56.44 \\
\hline \multirow{5}{*}{$\mathrm{H}-\mathrm{H}^{\mathrm{l}}$} & 10 & 1.11 & 62.52 \\
\hline & 11 & 2.18 & 96.76 \\
\hline & 12 & 4.03 & 155.96 \\
\hline & 13 & 3.21 & 129.72 \\
\hline & 14 & 3.06 & 124.92 \\
\hline \multirow{6}{*}{$\mathrm{I}-\mathrm{I}^{\mathrm{l}}$} & 15 & 1.67 & 80.44 \\
\hline & 16 & 1.49 & 74.68 \\
\hline & 17 & 1.20 & 65.40 \\
\hline & 18 & 1.75 & 83.00 \\
\hline & 19 & 2.13 & 95.16 \\
\hline & 20 & 2.06 & 92.92 \\
\hline \multirow{3}{*}{$J-J^{1}$} & 21 & 1.52 & 75.64 \\
\hline & 22 & 1.70 & 81.40 \\
\hline & 23 & 1.84 & 85.88 \\
\hline Average & & 2.29 & 100.15 \\
\hline
\end{tabular}

\section{i. Geological modelling of the Anomalies along the} Profiles.

The various profiles reveals the configuration of the depth to the anomalous bodies (the sedimentary infilling) in the study area. 


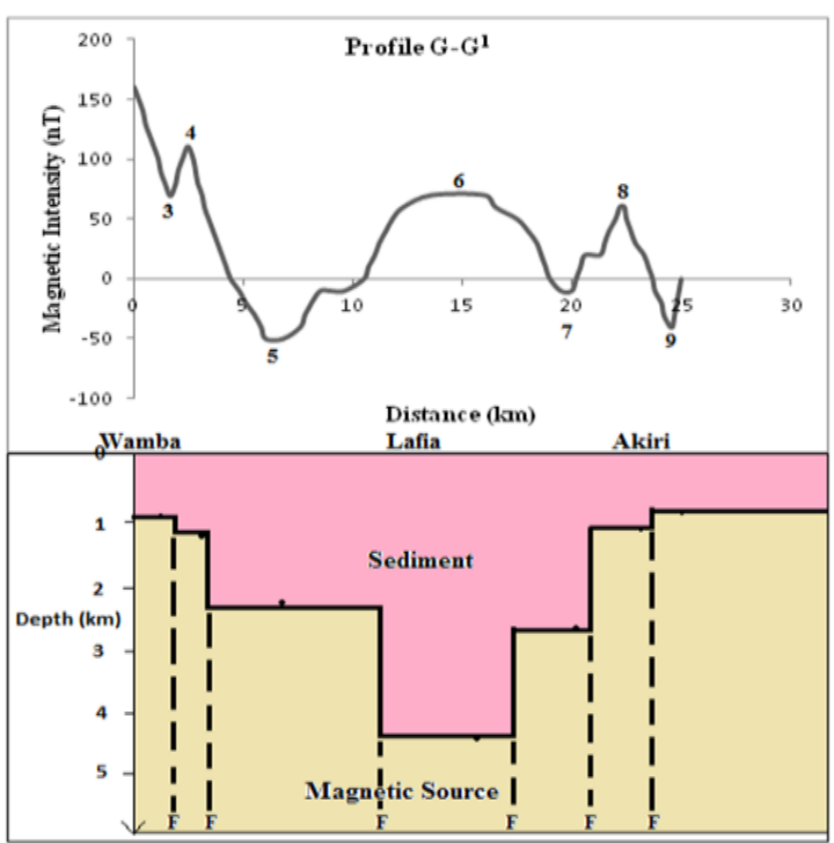

Fig 7a : Showing Model of Profile G-G ${ }^{1}$

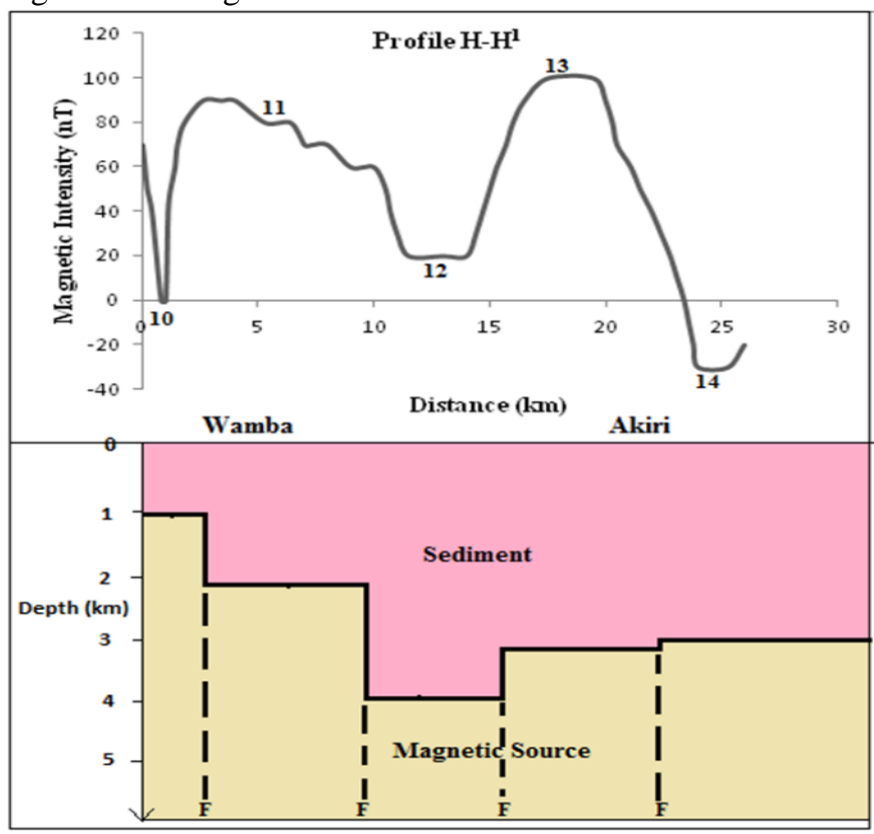

Fig $7 \mathrm{~b}$ : Showing Model of Profile $\mathrm{H}-\mathrm{H}^{1}$

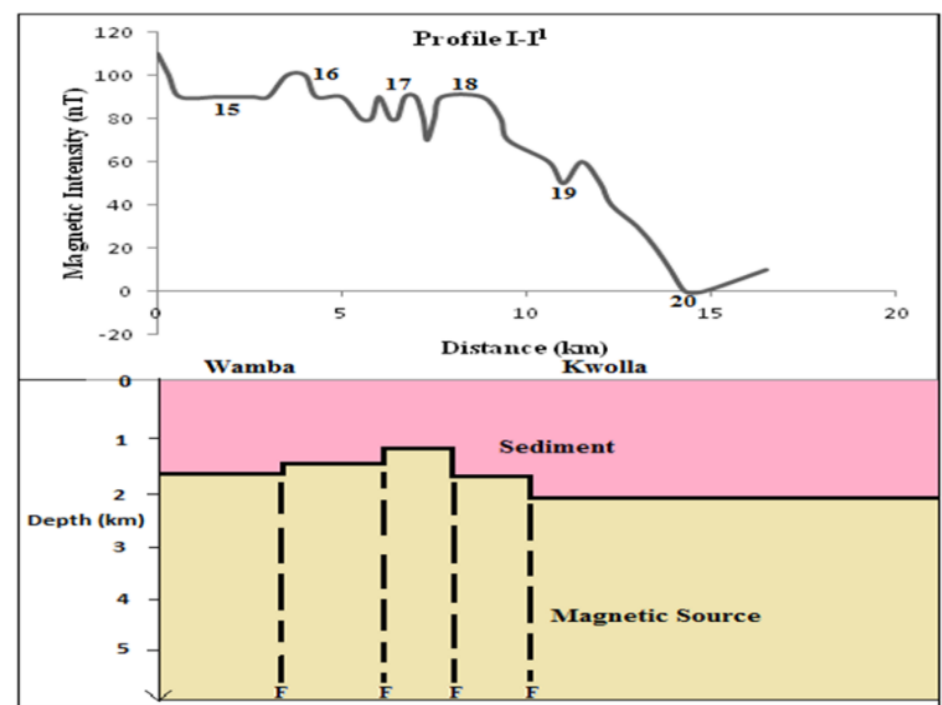

Fig 7c : Showing Model of Profile I-I

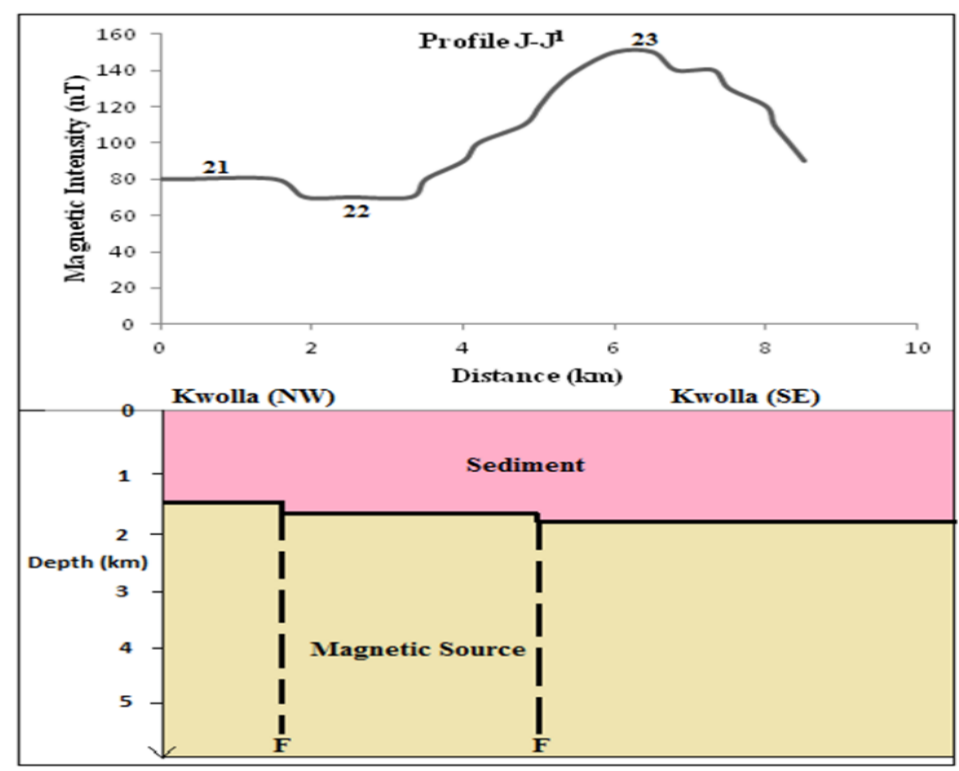

Fig 7d : Showing Model of Profile J-J ${ }^{1}$

Figs $7 \mathrm{a}-7 \mathrm{~d}$ above show the various models of each profile. Juxtaposing these profiles on the geological map (Fig 1) of the study area, it depicts that the deeper sources occurs around Cretaceous sedimentary rocks area. It can be observed that around Ajo, Obi, Keana, Abudem, Awena and areas between Ungwan Mai Samari and Kolen towns thicker sedimentary covers exist.

Figure 8 below shows the depth distribution on a plane view while Figure 9shows the 3- D view of the study area clearly showing that Lafia axis is more depressed hence thick sedimentary cover which also corresponds to the cretaceous sedimentary area. 


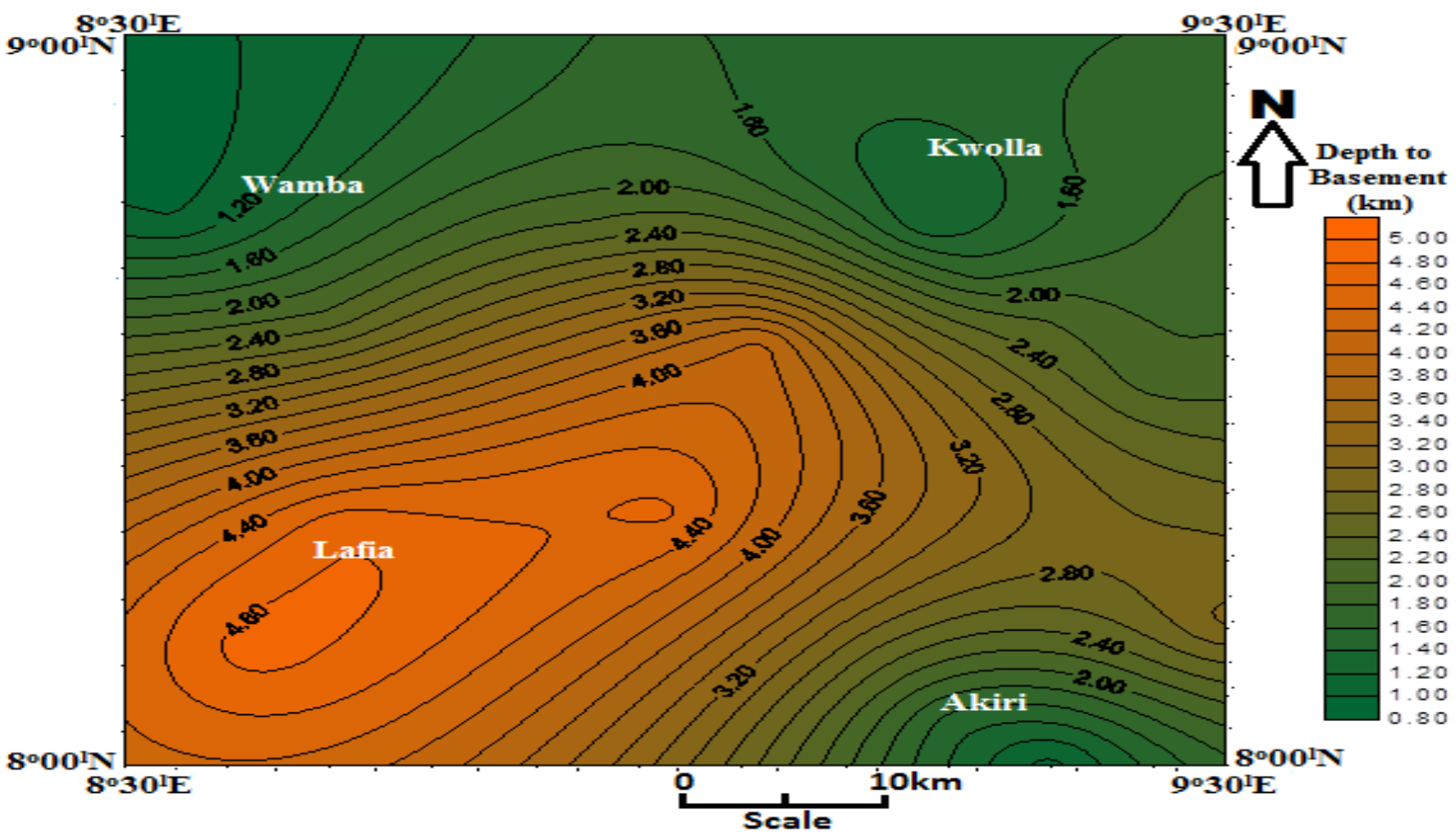

Fig.8: Tomography map of depth to the top magnetic sources in the area

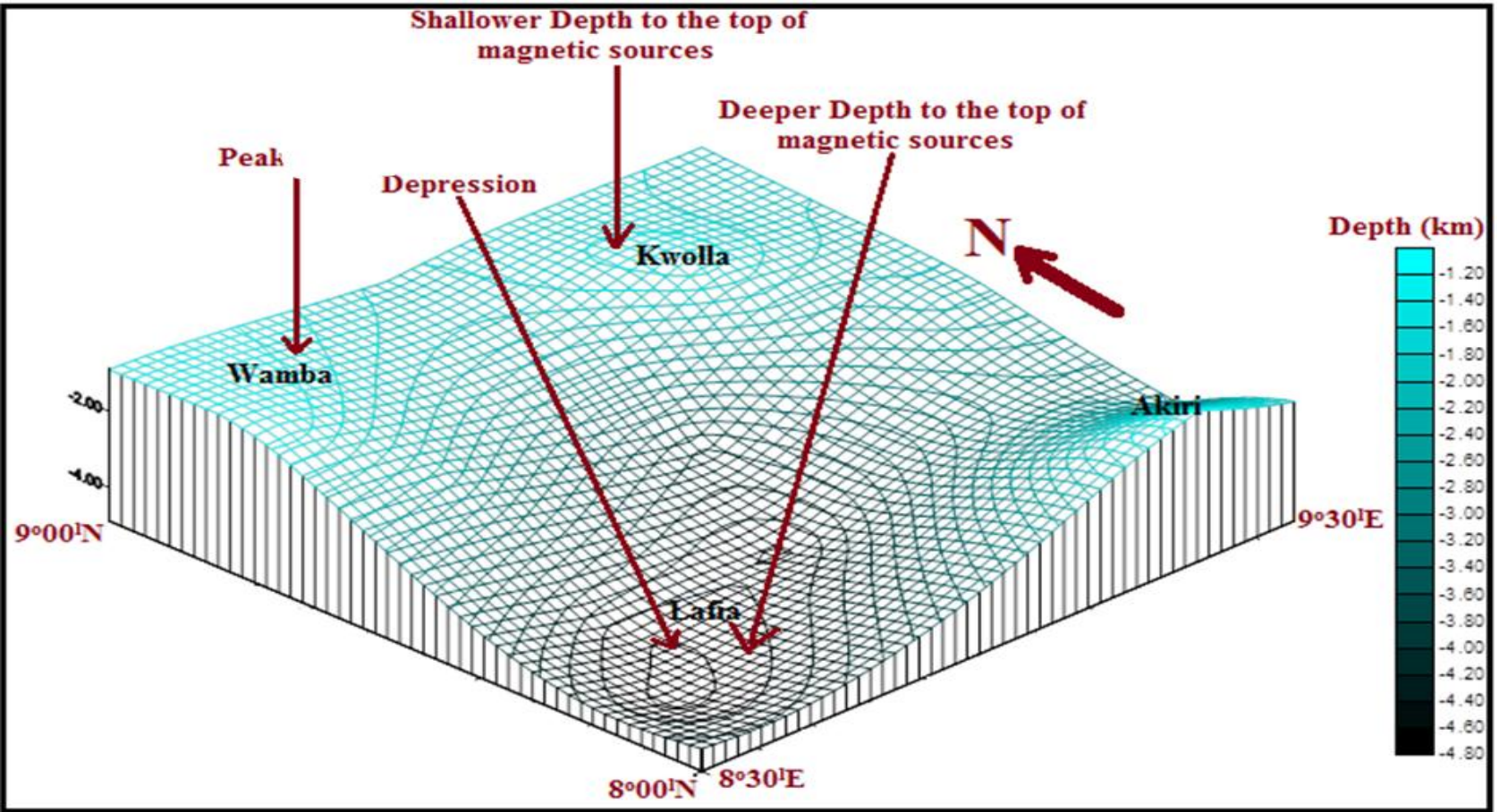

Fig.9: Real view model of depth to the top of magnetic sources in the area

\section{Estimation of Temperature at Depth}

Temperature at depth across the study area was estimated using equation given by Onwuemesi (1997)::

$\mathbf{T}_{\mathbf{h}}=\mathbf{m h}+\mathbf{T}_{\mathbf{0}}$

7

Where $\mathrm{T}_{\mathrm{h}}=$ temperature in ${ }^{0} \mathrm{C}$ at depth $(\mathrm{h}), \mathrm{m}=$ geothermal gradient, $\mathrm{h}=$ depth of interest;

$$
\mathrm{T}_{\mathrm{o}}=\text { surface temperature }
$$

For the calculation of the temperature at depth within the study area, the following obtained values and assumptions were used:

$$
\mathrm{T}_{\mathrm{o}}=27^{0} \mathrm{C} \text { (Nimet, 2016) } \mathrm{m}=32^{\circ} \mathrm{C} / \mathrm{km} \text { (Bello et al., 2017), } \mathrm{h}=0.86 \text { to } 4.89 \mathrm{~km} \text {. }
$$

The result of this calculation is shown in Table 1 and the values obtained range between 54.52 and $183.48^{\circ} \mathrm{C}$ with an average 
of $100.15^{\circ} \mathrm{C}$. Fig. 11 shows the distribution of the temperature within the study area. Both oil window and thermogenic gases are likely to occur around the southern to central parts of the study area and this is supported by Wright et al., (1985) and Chinwuko et al., (2012).

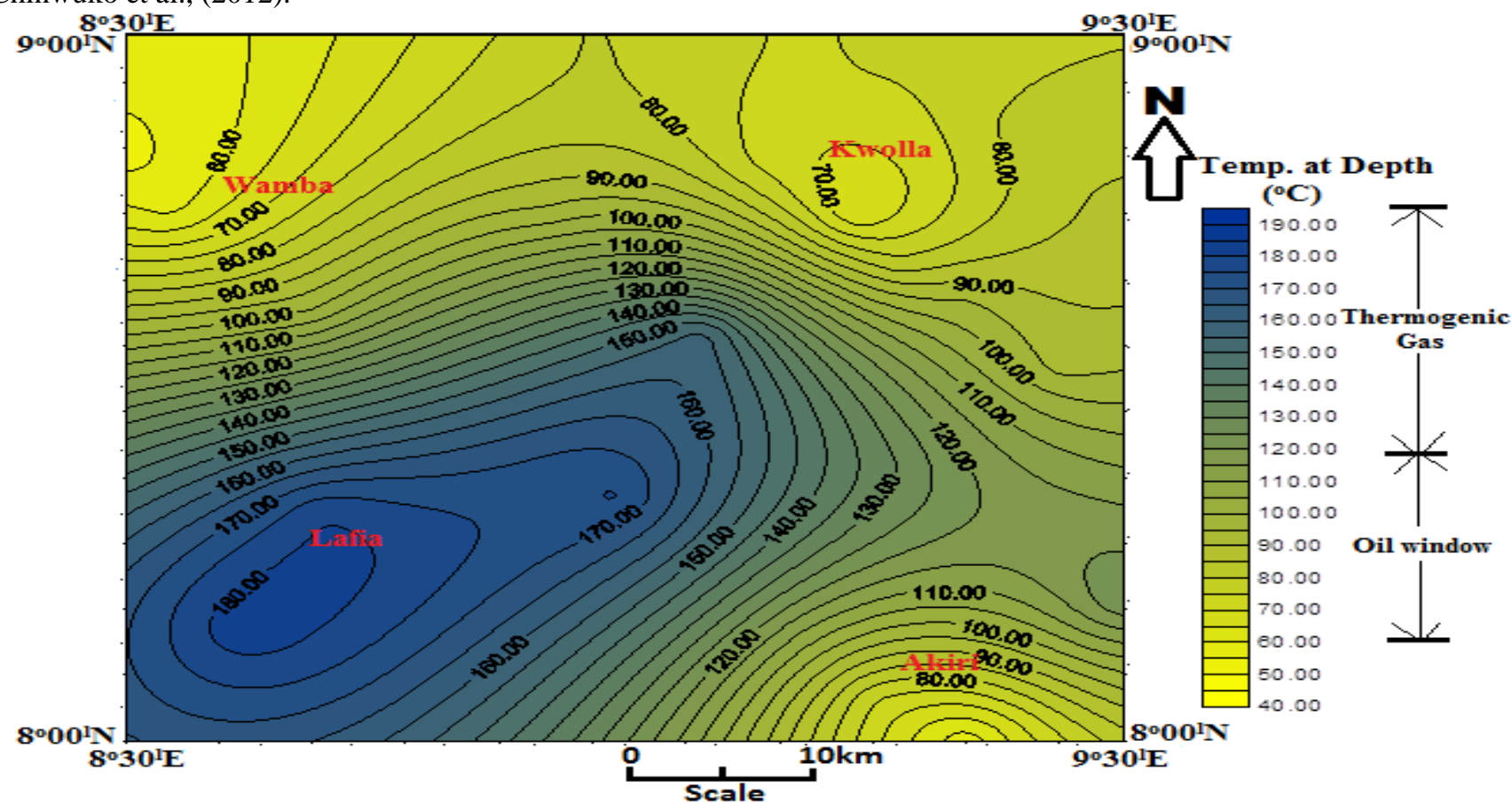

Fig.10: Map Distribution of Temperature at Depth across the study area $\quad\left(\right.$ Contour Interval $10^{\circ} \mathrm{C}$ )

\section{REFERENCES}

[1] Ajakaiye, D.E., Hall, D.H., Miller, T.W, Verherjen, P.J.T., Awad, M.B. \& Ojo, S.B. (1986).Aeromagnetic anomalies and tectonic trends in and around the Benue Trough Nigeria. Nature, 319, pp. 582-584.

[2] Ajibade, A.C. (1982). The Origin of the Older Granite of Nigeria: Some evidence from the Zungeru region. Nigeria Jour. Of Min. and Geol., 19, 223-230.

[3] Anudu, G.K., Onuba, L.N., Onwuemesi, A.G. \& Ikpokonte, A.E. (2012). Analysis of aeromagnetic data over Wamba and its adjoining areas in north-central Nigeria. Earth Science Resource Journal, Vol.16, no. 1, pp. $25-33$.

[4] Bello, R.,Ofoha C.C \& Wehiuzo, N. (2017): Geothermal Gradient, Curie Point Depth and Heat Flow Determination of Some Parts of Lower Benue Trough and Anambra Basin, Nigeria, Using High ResolutionAeromagnetic Data.Physical Science International Journal. 15 (2): 1-11, 2017; Article no.PSIJ.34654

[5] Chinwuko, A., Onwuemesi, A., Anakwuba, E., Onuba, L., \& Nwokeabia, N. (2012). Interpretation of Aeromagnetic Anomalies over parts of Upper Benue Trough and Southern Chad Basin, Nigeria. Advances in Applied Science Research, 3(3), 1757- 1766.

[6] Corell, L., \& Grauch, V.J.S., (1985). Mapping basement magnetization zones from aeromagnetic data in the San Juan Basin, New Mexico, in Hinze, W.J., ed., The utility of regional gravity and magnetic anomaly maps: Society of Exploration Geophysicists: Tulsa, Oklahoma, p.181-197

[7] Davis, J. C. (1973). Statistics and Data Analysis in Geology. Wiley and Sons, London.

[8] Dobrin, B.M. \& Savit, C.H. (1988) Introduction to Geophysical Prospecting. 4th Edition, McGraw-Hill

[9] Dow, W.G. (1978). Petroleum source beds on continental slopes and rises (2). AAPG Bulletin, vol. 62

[10] Gluyas, J. \& Swarbrick, R. (2005). Petroleum Geoscience. Blackwell Science, Oxford, 358pp.

[11] Hinze, W. J., (1990): ed., Proceedings of the International Meeting on Potential Fields in Rugged Topography: Institut de G'eophysique de Universit'e de Lausanne, Bulletin no. 7.

[12] Igwesi, D.I., \& Umego, M.N. (2013). Interpretation of Aeromagnetic Anomalies over some parts of Lower Benue Troughusing Spectral
Analysis Technique. International Journal of Scientific and Technology Research, Vol. 2, no. 8, pp. 153-165.

[13] Ikumbur, E. B., Onwuemesi, A. G., Anakwuba, E. K., Chinwuko, A. I., Usman, A.O.,\&Okonkwo, C. C. (2013). Spectral Analysis of Aeromagnetic Data over Part of the Southern Bida basin, West-Central Nigeria.International Journal of Fundamental Physical Sciences, vol. 3, no. 2, pp 27-31.

[14] Likkason, O. K., Singh G. P. \& Samaila N. K., (2013) A Study of the Middle Benue Trough (Nigeria) Based on Geological Application and Analyses of Spectra of Aeromagnetic Data, Energy Sources, Part A Recovery, Utilization, and Environmental Effects, 35:8, 706-716, DOI 10.1080/15567036.2010.514588

[15] Macleod, W.N., Turner, D.C. \& Wright, E.P. (1971). The Geology of Jos Plateau. Geological Survey of Nigeria, Bull. No.32, Vol. 2, P p.

[16] Negi, J., Agrawal, P., \& Rao, K. (1983). Three-dimensional model of the Koyna area of Maharashtra State (India) basedon the spectral analysis of aeromagnetic data. Geophysics, 48(7), 964-974.

[17] Nimet (2016). Nigeria Climate Review Bulletin 2015. Nigerian Meteorological Agency. NIMET-No.001.

[18] Nur, A., Onuoha, K. M.,\& Ofoegbu, C. O. (1994). Spectral analysis of aeromagnetic data over the Middle Benue Trough. Journal of Mining and Geology, 30, $211-217$.

[19] Nwazepu, A. U. (1992). Hydrocarbon Exploration in Frontier Basin The Nigeria Chad Basin Experience. Presented at the $28^{\text {th }}$ Annual Conference of the Nigerian Mining and Geosciences Society, Port-Harcourt.

[20] Obaje, N., Musa, M., Odoma, A., \& Hamza, H. (2011). The Bida Basin in north-central Nigeria: sedimentology and Petroleum geology. Journal of Petroleum and Gas Exploration Research Vol, 1(1), 001-013.

[21] Obiora, S.C. (2009). Field measurements in descriptions of igneous and metamorphic rocks. In Lambert-Aikhionbare, D.O. and Olayinka, A.I. (eds.) Proceedings of Field Mapping Standardisation Workshop,Ibadan University Press, Pp.105-125.

[22] Olasehinde, P.I., Pal, P.C. \& Annor, A.E. (1990). Aeromagnetic anomalies and structural lineament in the Nigerian Basement Complex. Journal of African Earth Sciences, vol. 11, vo. 3/4.

[23] Onwuemesi, A.G. (1997). One Dimensional Spectral Analysis of Aeromagnetic Anomalies and Curie Depth Isotherm in the Anambra Basin of Nigeria. Journal of Geodynamics, vol. 23, No.2, pp. 95-107.

[24] Onyedim, G. C., Awoyemi, M. O, Ariyi, E. A. \& Arubayi, J. B. (2006) Aeromagnetic imaging of the basement morphology in part of the 
Middle Benue Trough, Nigeria. Journal of Mining and Geology, Vol.42, No. 2, Pp. 157-163.

[25] Paterson, N.R. \& Reeves, C.V. 1985. Applications gravity and magnetic surveys: the state-of-the art in1985. Geophysics 50, Pp. 2558-94.

[26] Spector, A., \& Grant, F.S. (1970): Statistical models for interpreting aeromagnetic data. Geophysics, 35:293-302.

[27] Telford, W. M., Geldart L. P., \& Sheriff R. E., (1990): Applied geophysics, 2nd ed.: Cambridge University Press

[28] Wright, J.B., Hastings, D.A., Jones, W.B., \&Williams, H.R. (1985). Geology and Mineral Resources of West Africa. George Allen and Unwin (Publishers) Limited, London, UK, 187p. 